\title{
Silicon Heterojunction Solar Cells with p-Type Silicon Carbon Window Layer
}

\author{
Chia-Hsun Hsu ${ }^{1}$, Xiao-Ying Zhang ${ }^{1}$, Ming Jie Zhao ${ }^{1}$, Hai-Jun Lin ${ }^{1}$, Wen-Zhang Zhu ${ }^{1}$ and \\ Shui-Yang Lien $1,2, *$ \\ 1 School of Opto-electronic and Communication Engineering, Xiamen University of Technology, \\ Xiamen 361024, China \\ 2 Department of Materials Science and Engineering, Da-Yeh University, Chunghwa 51591, Taiwan \\ * Correspondence: sylien@xmut.edu.cn
}

Received: 31 May 2019; Accepted: 31 July 2019; Published: 3 August 2019

\begin{abstract}
Boron-doped hydrogenated amorphous silicon carbide (a-SiC:H) thin films are deposited using high frequency 27.12 MHz plasma enhanced chemical vapor deposition system as a window layer of silicon heterojunction (SHJ) solar cells. $\mathrm{The}^{\mathrm{CH}_{4}}$ gas flow rate is varied to deposit various $\mathrm{a}-\mathrm{SiC}: \mathrm{H}$ films, and the optical and electrical properties are investigated. The experimental results show that at the $\mathrm{CH}_{4}$ flow rate of $40 \mathrm{sccm}$ the a-SiC:H has a high band gap of $2.1 \mathrm{eV}$ and reduced absorption coefficients in the whole wavelength region, but the electrical conductivity deteriorates. The technology computer aided design simulation for SHJ devices reveal the band discontinuity at $\mathrm{i} / \mathrm{p}$ interface when the a-SiC:H films are used. For fabricated $\mathrm{SHJ}$ solar cell performance, the highest conversion efficiency of $22.14 \%$, which is $0.33 \%$ abs higher than that of conventional hydrogenated amorphous silicon window layer, can be obtained when the intermediate band gap (2 eV) a-SiC:H window layer is used.
\end{abstract}

Keywords: heterojunction; silicon carbide; band gap; solar cell; crystalline silicon

\section{Introduction}

Solar energy is on the edge of becoming one of the main energy sources, and crystalline silicon (c-Si) solar cells are currently a dominant product in the photovoltaic market. Due to the increasing cost of processed crystalline silicon ingots over the past years, the silicon wafer thickness has been demanded to decrease for solar cell fabrication. This trend was stopped due to the bending of thin wafers during high temperature processing of standard c-Si solar cells, and thus results in lots of efforts focusing on technologies for low material usage. Amorphous-crystalline silicon heterojunction (SHJ) solar cells are a hot topic because of their lower processing temperature (below $250{ }^{\circ} \mathrm{C}$ ) and a higher open-circuit voltage $\left(\mathrm{V}_{\mathrm{oc}}\right)$ in comparison to homojunction c-Si devices. A high conversion efficiency of over $26 \%$ of SHJ solar cells has been achieved [1]. The SHJ solar cells use a c-Si absorber while the other components have a thin-film structure. An intrinsic hydrogenated amorphous silicon (a-Si:H) provides excellent passivation of c-Si surface and carrier selectivity [2,3]. Unlike the homojunction c-Si cells with metals directly contacting to absorber, in $\mathrm{SHJ}$ the recombination-active contacts are replaced by passivated contacts, where semiconductor layers are between absorber and metal. Therefore, SHJ cells have a high $\mathrm{V}_{\text {oc }}$ of larger than 720-740 $\mathrm{mV}$ [4-6]. The thin-film components are deposited using plasma enhanced chemical vapor deposition (PECVD), which is a widely accepted technique for thin-film production. The primary reason for its acceptance is its capability to operate at lower temperatures than thermally driven CVD. In PECVD a plasma is usually ignited and sustained by applying a high frequency voltage to a low-pressure gas, leading to inelastic collisions between electrons and gas molecules forming highly reactive species without significantly raising the gas temperature. A well-known loss of SHJ solar cells 
is parasitic absorption loss of blue light of a-Si:H layers on the light-entering side [7-9]. The ideal thin film for a window layer of SHJ solar cells should have low light absorption, low resistivity, and high conductivity. Several strategies are being designated to help solve this problem such as wider/indirect band gap materials, thinner layers or interdigitated back contact solar cells [8-13]. Incorporating carbon or oxygen into a-Si:H matrix widens the band gap in a range between 1.7 to $2.7 \mathrm{eV} \mathrm{[14,15],}$ reducing the absorption coefficient and parasitic absorption for a given layer thickness. For an a-SiC:H film with a band gap of the photoconductivity and dark conductivity $1.8-2 \mathrm{eV}$, the photoconductivity and photosensitivity are $10^{-4} \mathrm{~S} / \mathrm{cm}$ and $10^{6}$, respectively. The photoconductivity of a-SiC:H with a band gap above $2.2 \mathrm{eV}$ degrades to about $10^{-10} \mathrm{~S} / \mathrm{cm}$. Although properties of a-SiC:H have been widely studied, the effect of the films on performance of SHJ solar cells is not fully understood.

In this study, different p-type a-SiC:H films are prepared by high frequency $27.12 \mathrm{MHz}$ PECVD. The gas flow rate of $\mathrm{CH}_{4}$ is varied to obtain a-SiC:H films with different band gap, photoconductivity, dark conductivity, and atomic composition. The transmittance and absorption spectra of the p-type a-SiC:H films were measured by a UV-visible spectrometer. The band gap of the films was estimated by Tauc plot with the equation:

$$
(\alpha h v)^{1 / n}=A\left(h v-E_{g}\right),
$$

where $\alpha$ is the absorption coefficient, $h v$ is the incident light energy, $A$ is a proportion constant, and $E_{g}$ is the band gap. The value of exponent $n$ determines the nature of electronic transition. For direct transition, $n=1 / 2$ and for indirect transition, $n=2$. The dark conductivity of the films was measured at room temperature using a source-measure unit (Keithley 2400). The photoconductivity of the films was obtained by a solar simulator under AM1.5G $\left(100 \mathrm{~mW} / \mathrm{cm}^{2}\right)$. The atomic ratio of the films were measured by an X-ray photoelectron spectroscopy (XPS). The current density-voltage (J-V) curves and external quantum efficiency (EQE) of the SHJ solar cells with different p-type layer were measured under AM1.5G conditions by a solar simulator consisting of xenon lamp and halogen lamp.

\section{Experimental}

Boron-doped a-SiC:H film films were prepared by using $27.12 \mathrm{MHz}$ plasma enhanced chemical vapor deposition (PECVD) with a gas mixture of $\mathrm{SiH}_{4}, \mathrm{H}_{2}, \mathrm{~B}_{2} \mathrm{H}_{6}$ and $\mathrm{CH}_{4}$ on glasses and silicon wafers. The glasses were cleaned with deionized water, acetone, alcohol, and deionized water in sequence at room temperature. The wafers were cleaned by standard Radio Corporation of America process (RCA) processes, followed by a dip in $2 \%$ hydrogen fluoride. Then, the substrates were blow-dried by nitrogen gas. During a-SiC:H deposition, the substrate temperature was $250{ }^{\circ} \mathrm{C}$, and the pressure was 0.6 Torr. The $\mathrm{CH}_{4}$ gas flow rate was varied from 0 to $50 \mathrm{sccm}$. The $\mathrm{H}_{2}$ flow rate was changed from 90 to $40 \mathrm{sccm}$ to keep the total flow rate of $\left(\mathrm{CH}_{4}+\mathrm{H}_{2}\right)$ at $90 \mathrm{sccm}$. Detailed deposition parameters are summarized in Table 1. For SHJ solar cell fabrication, the scheme of the device structure is shown in Figure 1 . N-type n-type c-Si wafers $\left(2 \times 2 \mathrm{~cm}^{2}\right)$ with resistivity of $0.5 \Omega$-cm and thickness of $100 \mu \mathrm{m}$ were used as an absorber layer. The wafers were textured by solutions containing $\mathrm{NaOH}(2 \mathrm{wt} \%)$ and isopropyl alcohol (4 vol\%) for $25 \mathrm{~min}$ to produce random pyramidal surfaces. Then, the wafers were cleaned by RCA process, and transferred to a vacuum chamber. A $5 \mathrm{~nm}$-thick intrinsic a-Si:H layer was deposited on the both sides of the wafer to passivate dangling bonds on the wafer surfaces. Different p-type a-SiC:H films were then deposited on the wafer front side, and a n-type a-Si:H layer was deposited on the wafer rear side. The intrinsic, $\mathrm{p}$-type and $\mathrm{n}$-type layers were deposited by PECVD at $250{ }^{\circ} \mathrm{C}$. An indium tin oxide (ITO) with a thickness of $80 \mathrm{~nm}$ and metal grids were deposited on both sides by radio-frequency magnetron sputtering at room temperature. The surface texturing and ITO was used for minimizing the front surface reflection. Cell fabrication was finished with thermally evaporated silver metal grid electrodes on the both sides of the wafer. 
Table 1. Deposition conditions for plasma enhanced chemical vapor deposition (PECVD) hydrogenated amorphous silicon carbide (a-SiC:H) thin films.

\begin{tabular}{cc}
\hline Parameter & Value \\
\hline Power $(\mathrm{W})$ & 10 \\
Pressure $(\mathrm{Pa})$ & 80 \\
Substrate Temperature $\left({ }^{\circ} \mathrm{C}\right)$ & 250 \\
Thickness $(\mu \mathrm{m})$ & 0.5 \\
Process time $(\mathrm{min})$ & 40 \\
$\mathrm{SiH}_{4}$ flow rate $(\mathrm{sccm})$ & 20 \\
$\mathrm{~B}_{2} \mathrm{H}_{6}$ flow rate $(\mathrm{sccm})$ & 10 \\
$\mathrm{CH}_{4}$ flow rate $(\mathrm{sccm})$ & $0 \sim 50$ \\
$\mathrm{H}_{2}$ flow rate $(\mathrm{sccm})$ & $90 \sim 40$ \\
\hline
\end{tabular}

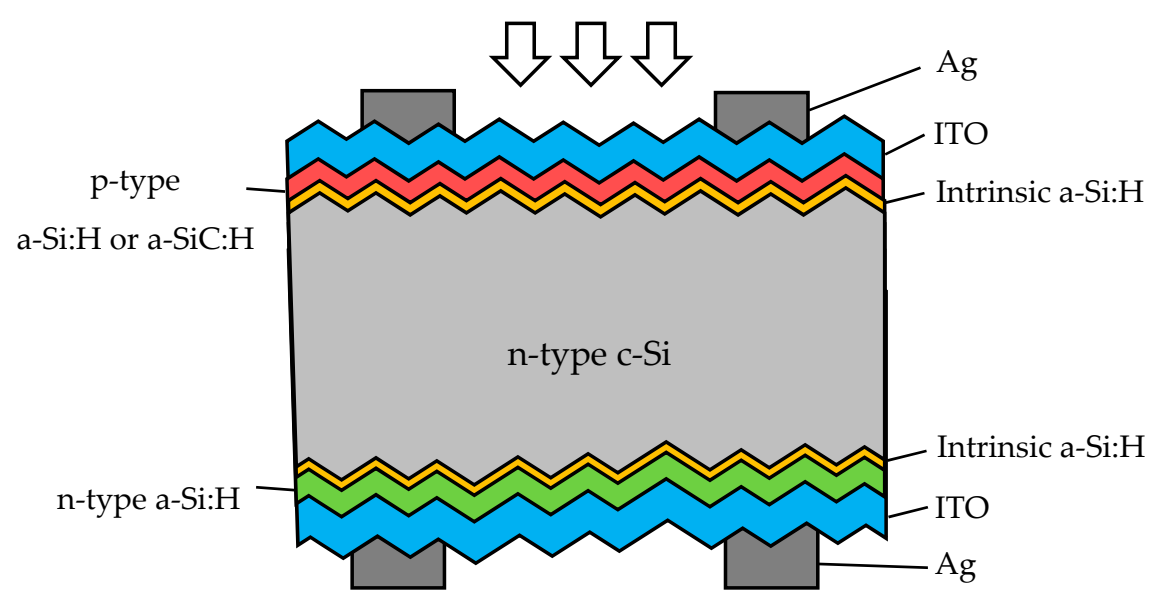

Figure 1. Scheme of a silicon heterojunction (SHJ) solar cell. The arrows indicate the incident light.

\section{Results}

A window layer with a low light absorption is very important for SHJ solar cells as it in turn means that more light can be absorbed in the absorber layer. Moreover, light absorbed in the window layer would not contribute to device current density. The optical absorption coefficient, $\alpha$, is evaluated using transmittance and reflectance spectra according to the equation:

$$
\alpha=\frac{-1}{d} \ln \left(\frac{T}{1-R}\right)
$$

where $d$ is the film thickness, $T$ is the transmittance, and $R$ is the reflectance. The thickness of the thin films increases with increasing the $\mathrm{CH}_{4}$ gas flow rate. However, in this study, the thickness is kept to $15 \mathrm{~nm}$ for all the p-type layers. Figure 2 shows the absorption coefficient of a-SiC:H deposited with different $\mathrm{H}_{2} / \mathrm{CH}_{4}$ gas ratio in the wavelength range of $200-1000 \mathrm{~nm}$. Without $\mathrm{CH}_{4}$ gas, the film is a-Si:H and the absorption coefficient is the largest over the whole investigated wavelength region. The absorption coefficient decreases when the $\mathrm{CH}_{4}$ flow rate increases. This might be due to the increase of the incorporation of $\mathrm{C}$ into a-Si:H network, leading to reduction in absorption coefficient. For c-Si solar cells having the strongest absorption, around $600 \mathrm{~nm}$ wavelength, the absorption coefficient at this wavelength $\left(\alpha_{600}\right)$ can be used for comparison. The value of $\alpha_{600}$ is about $4.5 \times 10^{4} \mathrm{~cm}^{-1}$ at the $\mathrm{CH}_{4}$ flow rate of 0 . When the gas flow rate larger than $10 \mathrm{sccm}, \alpha_{600}$ decreases to below $10^{4} \mathrm{~cm}^{-1}$, which is the least requirement for a window layer of silicon-based solar cells. 


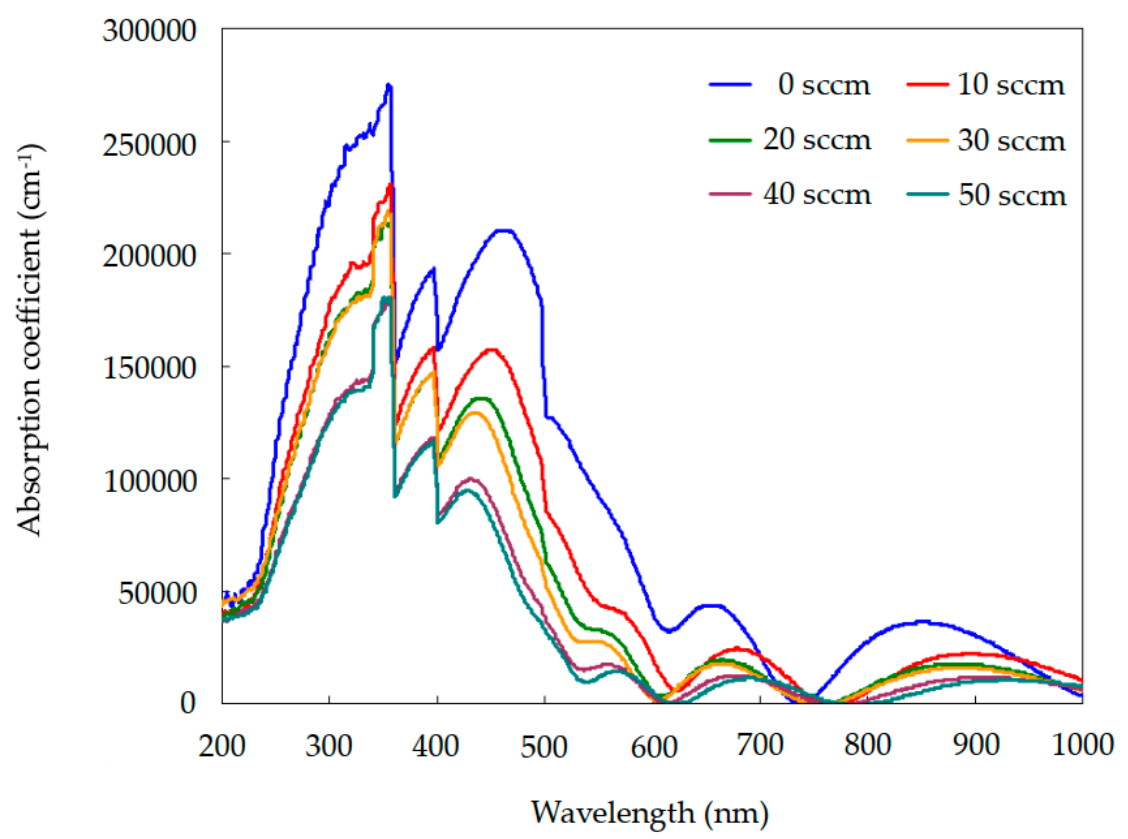

Figure 2. Absorption coefficient of a-SiC: $\mathrm{H}$ films with different $\mathrm{H}_{2} / \mathrm{CH}_{4}$ gas flow ratio as a function of wavelength.

Figure 3 shows the optical band gap, photoconductivity and dark conductivity of the a-Si:H films as a function of $\mathrm{CH}_{4}$ gas flow rate. At $\mathrm{CH}_{4}$ gas flow rate of 0 , the deposited film has a band gap of $1.78 \mathrm{eV}$, which is a typical value of a-Si:H. The band gap significantly increases from 1.86 to $2.11 \mathrm{eV}$ when the $\mathrm{CH}_{4}$ gas flow rate increases from 10 to $50 \mathrm{sccm}$. The increased band gap results from the incorporation of $\mathrm{C}$ into the films. The higher band gap indicates that a cut-off wavelength would shift toward lower wavelength region and the film is relatively more transparent to light. The increased $\mathrm{CH}_{4}$ flow rate could enhance the dissociation of the $\mathrm{CH}_{4}$ and $\mathrm{SiH}_{4}$ molecules during PECVD deposition process. This leads to more Si-C bonds in the deposited films. However, it should be noted that carbon incorporation into a-Si:H would induce more structural disorder and defects, deteriorating electrical properties of the films. It has been reported that the paramagnetic defects in a-SiC:H films are mainly related with carbon incorporation, which leads to development of structural disorder, i.e., homonuclear interatomic bonds ( $\mathrm{Si}-\mathrm{Si}, \mathrm{C}-\mathrm{C}$ ) [16-18]. In a mixed $\mathrm{sp}^{2}$ - and $\mathrm{sp}^{3}$-coordinated disordered carbon network, the possible types of paramagnetic defects can be dangling $\sigma$-bonds and unpaired $\pi$-electrons associated with a single $\mathrm{sp}^{2}$-coordinated carbon atom and a carbon cluster with an odd

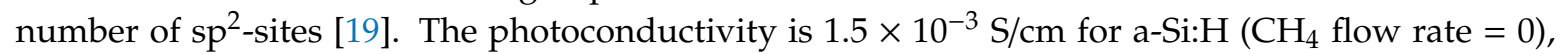
and it decrease significantly to $2.6 \times 10^{-6} \mathrm{~S} / \mathrm{cm}$ when the $\mathrm{CH}_{4}$ flow rate increases to $50 \mathrm{sccm}$. The dark conductivity shows a smaller influence by the $\mathrm{CH}_{4}$ flow rate, and ranges from 1 to $6 \times 10^{-9} \mathrm{~S} / \mathrm{cm}$. Therefore, there is a tradeoff between the gain in band gap and the loss in electrical properties at increasing $\mathrm{CH}_{4}$ flow rate.

Figure 4 shows the $\mathrm{Si}, \mathrm{C}$ and $\mathrm{B}$ elemental ratio measured by XPS. For the film deposited without $\mathrm{CH}_{4}$, the carbon atomic ratio is as low as $4.5 \%$, the silicon ratio is about $67 \%$, and boron ratio is around $28.5 \%$. The little carbon content is due to the contamination from environment as the carbon gas was not used during deposition. The increase in the $\mathrm{CH}_{4}$ flow rate from 10 to $50 \mathrm{sccm}$, the carbon atomic ratio obviously increases from $27 \%$ to $45 \%$, while the silicon and boron contents decrease. The boron content is in a range of $28.5 \%$ to $30.9 \%$ but decreases to $20.8 \%$ to $24 \%$ when the $\mathrm{CH}_{4}$ flow rate increases to $30-50 \mathrm{sccm}$. The incorporation of the carbon atoms into the films increases as the $\mathrm{CH} 4$ gas flow rate increases. The carbon atoms could replace the silicon or boron atoms sites. The boron content thus decreases with increasing the $\mathrm{CH}_{4}$ flow rate. This indicates that the increase in carbon content to certain level (in this case larger than silicon content) decreases doping efficiency of boron to the films. The boron is used as a dopant for creating p-type silicon thin-film layer. As the $\mathrm{CH}_{4}$ flow rate increases, 
the carbon content of the films increases, but the boron content decreases. The dark conductivity of the films thus decreases with increasing the $\mathrm{CH}_{4}$ flow rate.

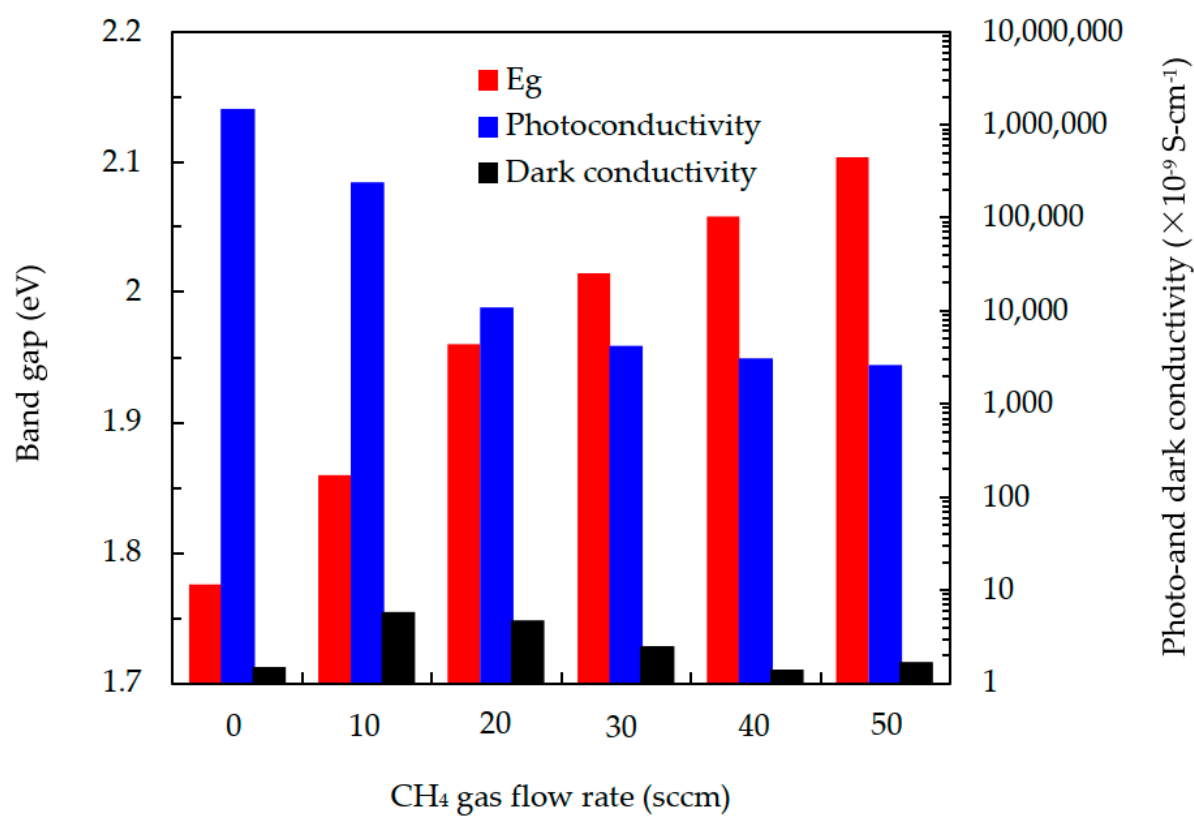

Figure 3. Band gap, photoconductivity and dark conductivity of the p-type a-SiC:H films deposited with different $\mathrm{CH}_{4}$ gas flow rate.

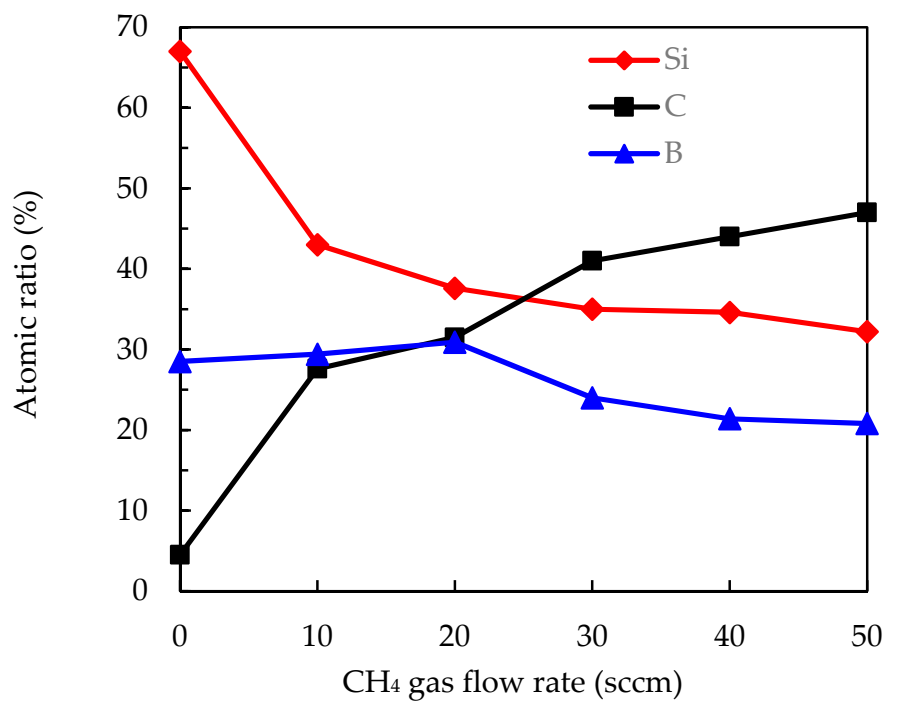

Figure 4. Atomic ratio of $\mathrm{Si}, \mathrm{C}$ and $\mathrm{B}$ of the a-SiC:H films deposited with different $\mathrm{CH}_{4}$ gas flow rate.

To gain an insight of the $\mathrm{SHJ}$ with different a-SiC:H window layers, the film properties are input into technology computer aided design (TCAD) simulation software. The device structure and parameters can be found elsewhere $[20,21]$. The a-SiC:H films with band gaps of $1.78(\mathrm{a}-\mathrm{Si}: \mathrm{H})$, 1.85 (a-SiC1), 2 (a-SiC2) and $2.1 \mathrm{eV}\left(\mathrm{a}-\mathrm{SiC} 3\right.$ ) are used, corresponding to $\mathrm{CH}_{4}$ gas flow rates of $0,10,30$ and $50 \mathrm{sccm}$, respectively. The detailed deposition parameters of the a-Si:H, a-SiC1, a-SiC2, a-SiC3 films are listed in Table 2. Figure 5 shows the photogeneration rate $(G)$ in logarithm versus the device depth for the SHJ cells with different a-SiC:H window layer. The light enters into the device from the p-type layer side. The depth indicates the distance from the front surface of the devices. In general, the highest photogeneration rate is at the surface of the light entering side, and then exponentially decreases as the depth increases. A close view of the surface is shown in the inset of Figure 5. It is 
clearly seen that a-Si:H window layer has the lowest photogeneration rate. The a-SiC1 with the band gap of $1.85 \mathrm{eV}$ leads to an increased generation rate. The generation rate further increases when a-SiC2 and a-SiC 3 are used, but the difference between these two curves is less significant. This infers that the gain in photocurrent due to the increased band gap would saturate when band gap reaches $2 \mathrm{eV}$.

Table 2. Deposition conditions for hydrogenated amorphous silicon (a-Si:H), a-SiC1, a-SiC2 and a-SiC3 thin films.

\begin{tabular}{lcccc}
\hline \multicolumn{1}{c}{ Parameter } & a-Si:H & a-SiC1 & a-SiC2 & a-SiC3 \\
\hline Power $(\mathrm{W})$ & 10 & 10 & 10 & 10 \\
Pressure $(\mathrm{Pa})$ & 80 & 80 & 80 & 80 \\
Substrate Temperature $\left({ }^{\circ} \mathrm{C}\right)$ & 200 & 200 & 200 & 200 \\
Thickness $(\mu \mathrm{m})$ & 0.5 & 0.5 & 0.5 & 0.5 \\
Process time $(\mathrm{min})$ & 40 & 40 & 40 & 40 \\
$\mathrm{SiH}_{4}$ flow rate $(\mathrm{sccm})$ & 20 & 20 & 20 & 20 \\
$\mathrm{~B}_{2} \mathrm{H}_{6}$ flow rate $(\mathrm{sccm})$ & 10 & 10 & 10 & 10 \\
$\mathrm{CH}_{4}$ flow rate $(\mathrm{sccm})$ & 0 & 10 & 30 & 50 \\
$\mathrm{H}_{2}$ flow rate $(\mathrm{sccm})$ & 90 & 80 & 60 & 40 \\
\hline
\end{tabular}

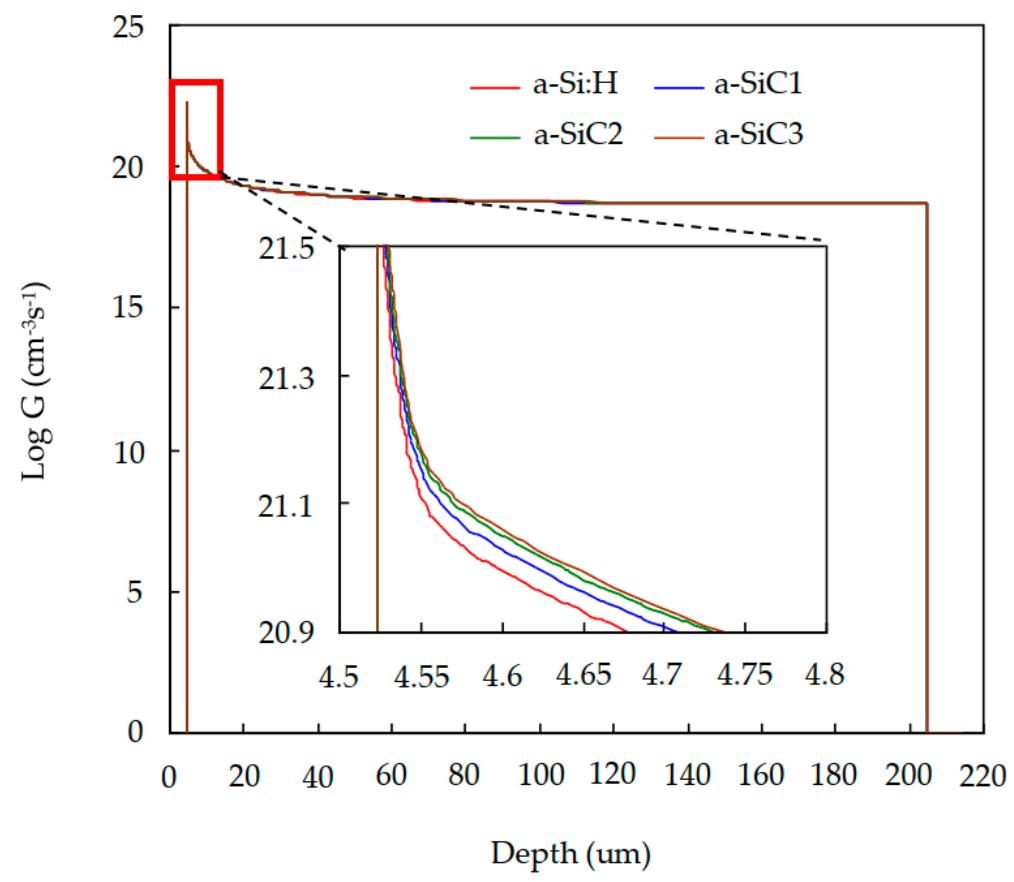

Figure 5. Depth profile of photogeneration rate $(\mathrm{G})$ of SHJ solar cells. The inset is the close view of the red-marked region.

Figure 6 shows the simulated band structure of the $\mathrm{SHJ}$ solar cells with p-type a-Si:H, a-SiC1, a-SiC2, and a-SiC3 window layers. In the TCAD simulation, the doping concentration of the p-type a-Si:H and a-SiC was $10^{19} \mathrm{~cm}^{-3}$. The values of the electron affinity for the p-type a-Si:H and a-SiC were set to 4 and $3.9 \mathrm{eV}$, respectively [22,23]. The work function values of the p-type a-Si:H layer and a-SiC layers were calculated to be 5.33 and $5.43 \mathrm{eV}$, respectively, which were in the range of literature values $[24,25]$. It can be seen that the carrier selectivity of the SHJ solar cells, in which electrons move toward $\mathrm{n}$-side as there is a barrier at front $\mathrm{i} / \mathrm{n}$ region and holes toward $\mathrm{p}$-side by tunneling. It is reported that for n-type SHJ solar cells, valence band offset at front amorphous/crystalline silicon interface is more crucial than conduction band offset [26]. Consider the p-type a-Si:H layer, the valence band offset (typically about $0.45-0.55 \mathrm{eV}$ ) occurs at $\mathrm{i} / \mathrm{n}$ interface, and this region cause hole accumulation, leading to an minority carrier inversion layer near the n-type c-Si surface. This inversion layer is known to play important role of reducing recombination rate of c-Si interface [27]. As the i-layer is very thin, which is 
$1 \mathrm{~nm}$ in this simulation and is less than $5 \mathrm{~nm}$ for actual devices, the holes can tunnel through the valence band barrier. The replacement of the p-type a-Si:H with a-SiC:H leads more bend bending, which is favor for increasing build-in potential and $\mathrm{V}_{\mathrm{oc}}$. However, it is observed that a discontinuity occurs at $\mathrm{p} / \mathrm{i}$ interface. It has been reported that for SHJ solar cells, discontinuity at the $\mathrm{p} / \mathrm{i}$ interface will result in an increase of carrier recombination rate and a reduction of hole collection at the interface [28,29]. The discontinuity becomes more and more obvious when the band gap of a-SiC:H films is higher. From this aspect, the intermediate band gap of a-SiC should be optimal for final device performance.

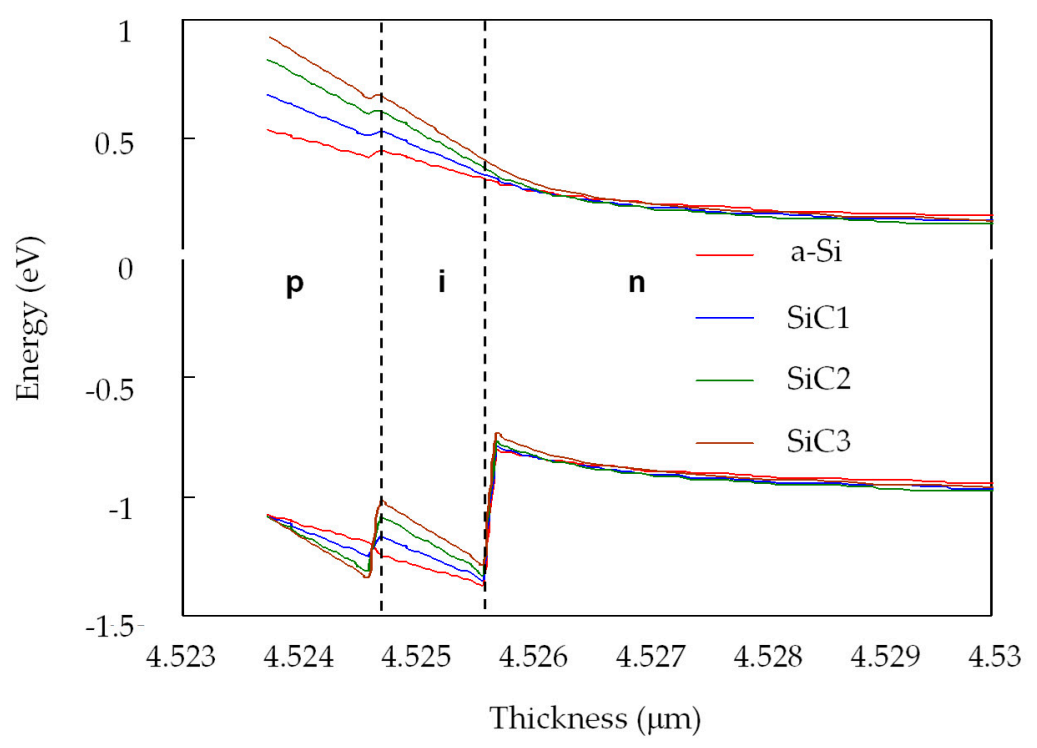

Figure 6. Simulated band structure of SHJ solar cells with different p-type a-SiC:H window layer.

Figure 7a shows the J-V curves and performance of the SHJ solar cells with different a-SiC:H window layers. The curves near $\mathrm{V}_{\mathrm{oc}}$ are shown in Figure $7 \mathrm{~b}$. It is seen that open-circuit voltage is $679 \mathrm{mV}$ when p-type a-Si:H is used. This value is relatively low as compared to that of state-of-the art HIT solar cells, which is beyond $720 \mathrm{mV}$, due to several possible reasons such as non-optimized intrinsic a-Si:H/c-Si interface or unsatisfied edge isolation. Therefore, the cell with a-Si:H window layer should only be used as a reference for comparison to observe the effect of a-SiC:H layer on performance of SHJ solar cells. The a-SiC:H window layers exhibit an increase in $\mathrm{V}_{\text {oc }}$ by 4 to $11 \mathrm{mV}$. The short-circuit current density $\left(\mathrm{J}_{\mathrm{sc}}\right)$ of the reference SHJ cells is $39.12 \mathrm{~mA} / \mathrm{cm}^{2}$ and increases for the cells with a-SiC1 layer, or with a-SiC2 layer. The $\mathrm{J}_{\mathrm{sc}}$ does not further increase for a-SiC3, which has the largest band gap among the a-SiC:H films. This is in accordance with the simulation result which shows the photogeneration rate for a-SiC3 is similar to the case of a-SiC2. The reduced collection efficiency of the holes due to the valence band offset might compensate the photocurrent gain brought by the larger band gap. This effect also leads to reduction in fill factor (FF). Besides, the conductivity of a-SiC:H films with higher carbon incorporation is lower. The FF decreases in the cases of those SHJ cells with high carbon-content a-SiC2 and a-SiC3. The series resistance of the $\mathrm{SHJ}$ cells can be extracted from the J-V curves by several methods [30-32]. Chang et al. [33] reported a simple solar cell parameter extraction method from a single J-V curve. By using this method, a plot of $d V / d J$ versus $\left[\left(J_{s c}+J-V / R_{s h}\right)^{-1} k T / q\right]$ is illustrated, where $\mathrm{J}$ is the measured current density, $\mathrm{V}$ is the applied voltage, $\mathrm{R}_{\mathrm{sh}}$ is the shunt resistance corresponding to the value of $\mathrm{dV} / \mathrm{dJ}$ at the short-circuit condition, and $\mathrm{kT} / \mathrm{q}$ is the thermal voltage. The series resistance can be obtained as the interception with the y-axis. The extracted series resistances are $1.46,1.82,2.17$, and $2.2 \Omega \mathrm{cm}^{2}$ for the $\mathrm{SHJ}$ cells with a-Si:H, a-SiC1, a-SiC2, and a-SiC3, respectively. The increased series resistance also accounts for the decreased FF. Overall, the SHJ cell with a-SiC2 (band gap of $2 \mathrm{eV}$ ) has the highest conversion efficiency ( $\eta$ ) of $22.16 \%$. 


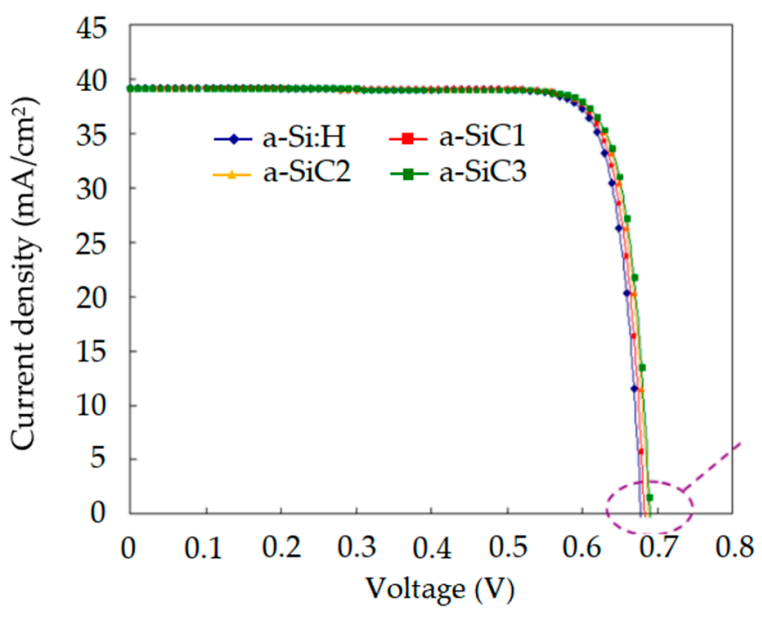

(a)

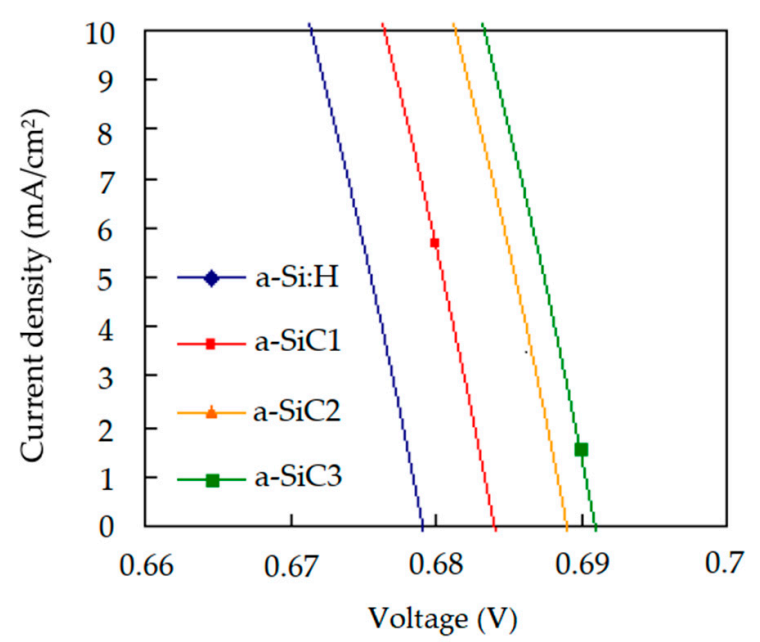

(b)

Figure 7. (a) Current density-voltage $(\mathrm{J}-\mathrm{V})$ curves and performance of the fabricated SHJ solar cells with different p-type a-SiC:H window layer. (b) Close-up view of the J-V curves near open-circuit voltage.

Figure 8 shows the EQE spectra of the SHJ solar cells with different p-type a-SiC:H window layer. The curves have nearly the same EQE values at long wavelengths, since the variation of the window layer would not significantly change the optical behavior at the rear side of the devices. For the short wavelengths, the a-Si:H window layer leads to the lowest spectral response. The a-SiC1 has the intermediate $\mathrm{EQE}$ values, and the a-SiC2 and $\mathrm{a}-\mathrm{SiC} 3$ have the similar spectral response. This result accounts for the $\mathrm{J}_{\mathrm{sc}}$ values. The cross-sectional TEM image of the fabricated SHJ solar cell with the p-type a-SiC2 window layer is shown in Figure 9. No ordered arrangement of the atoms can be observed in the p-type a-SiC2 layer, and thus the a-SiC2 layer is not crystallized.

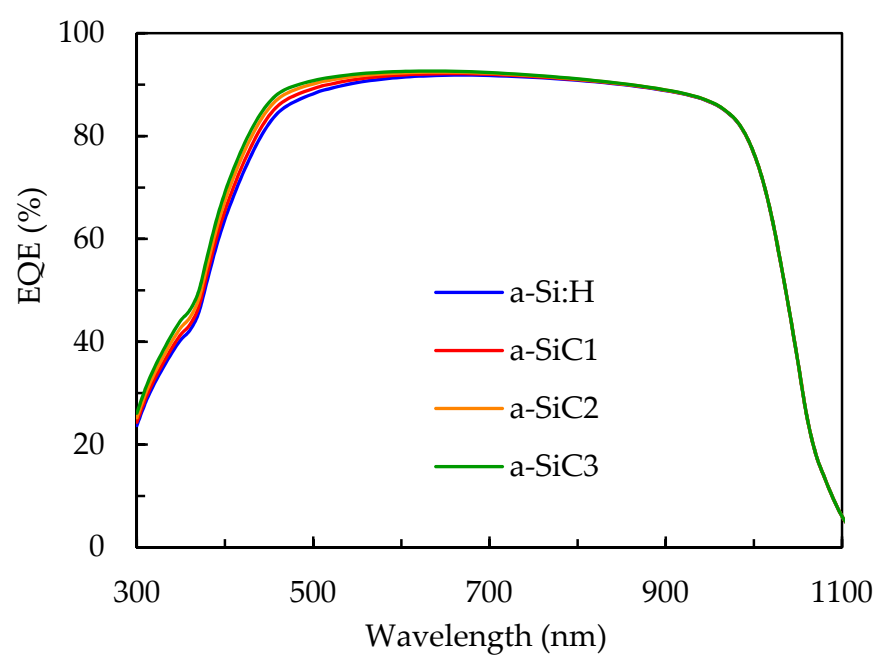

Figure 8. External quantum efficiency (EQE) spectra for the SHJ solar cells with different p-type a-SiC:H window layer. 


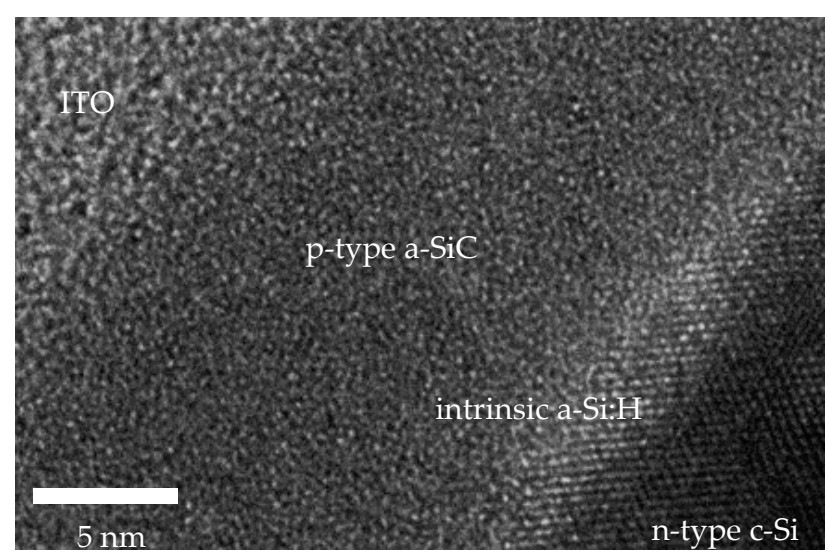

Figure 9. Cross-sectional transmission electron microscope (TEM) image of the silicon heterojunction solar cell with the p-type a-SiC2 layer.

\section{Conclusions}

P-type a-SiC:H films are deposited by 27.12 MHz PECVD with a gas mixture of $\mathrm{SiH}_{4}, \mathrm{~B}_{2} \mathrm{H}_{6}, \mathrm{H}_{2}$ and $\mathrm{CH}_{4}$. The $\mathrm{CH}_{4}$ gas flow rate is varied to deposit films with different band gap. The experimental shows that a higher $\mathrm{CH}_{4}$ flow rate leads to increase in band gap, reduction in absorption coefficient, but the photoconductivity significantly reduces. Furthermore, the XPS result reveals that the boron content decrease when carbon incorporation increases. Therefore, there is a balance between the gain in band gap and the loss in conductivity. The TCAD simulation indicates that the photocurrent seems to saturate for the a-SiC:H with a band gap of $2 \mathrm{eV}$. The band structure reveals a large band gap can have more band bending that could enhance $\mathrm{V}_{\mathrm{oc}}$, but band discontinuity presents at $\mathrm{i} / \mathrm{p}$ interface. This might reduce carrier collecting, and eventually lower $\mathrm{J}_{\mathrm{sc}}$ and FF of the devices. Finally, for SHJ solar cell fabrication, the cell with an intermediated band gap window layer exhibits the highest conversion efficiency of $22.14 \%$, which is about $0.33 \%$ abs higher than those that use the a-Si:H window layer.

Author Contributions: Experiments, C.-H.H. and S.-Y.L.; formal analysis, C.-H.H., S.-Y.L., X.-Y.Z., W.-Z.Z. and H.-J.L.; writing — original draft preparation, C.-H.H.; writing—review and editing, S.-Y.L.; visualization, X.-Y.Z.; funding acquisition, X.-Y.Z. and M.J.Z.

Funding: This work is sponsored by the science and technology project of Xiamen (No. 3502Z20183054) and the Science and Technology Program of the Educational Office of Fujian Province (No. JT180432). This work is also supported by the National Natural Science Foundation of China (grant No. 61704142).

Conflicts of Interest: The authors declare no conflict of interest.

\section{References}

1. Yoshikawa, K.; Kawasaki, H.; Yoshida, W.; Irie, T.; Konishi, K.; Nakano, K.; Uto, T.; Adachi, D.; Kanematsu, M.; Uzu, H.; et al. Silicon heterojunction solar cell with interdigitated back contacts for a photoconversion efficiency over 26\%. Nat. Energy 2017, 2, 17032. [CrossRef]

2. Taguchi, M.; Yano, A.; Tohoda, S.; Matsuyama, K.; Nakamura, Y.; Nishiwaki, T.; Fujita, K.; Maruyama, E. 24.7\% Record efficiency HIT solar cell on thin silicon wafer. IEEE J. Photovolt. 2014, 4, 96-99. [CrossRef]

3. DeWolf, S.; Descoeudres, A.; Holman, Z.C.; Ballif, C. High-efficiency silicon heterojunction solar cells: A review. Green 2012, 2, 7-24.

4. Mueller, T.; Wong, J.; Aberle, A.G. Heterojunction silicon wafer solar cells using amorphous silicon suboxides for interface passivation. Energy Procedia 2012, 15, 97-106. [CrossRef]

5. Descoeudres, A.; Allebé, C.; Badel, N.; Barraud, L.; Champliaud, J.; Debrot, F.; Faes, A.; Lachowicz, A.; Levrat, J.; Nicolay, S.; et al. Silicon Heterojunction Solar Cells: Towards Low-cost High-Efficiency Industrial Devices and Application to Low-concentration PV. Energy Procedia 2015, 77, 508-514. [CrossRef]

6. Stanislau, Y.; Herasimenka, W.J.D.; Bowden, S.G. $>750 \mathrm{mV}$ open circuit voltage measured on $50 \mu \mathrm{m}$ thick silicon heterojunction solar cell. Appl. Phys. Lett. 2013, 103, 053511. 
7. Holman, Z.C.; Descoeudres, A.; Barraud, L.; Fernandez, F.Z.; Seif, J.P.; Wolf, S.D.; Ballif, C. Current Losses at the Front of Silicon Heterojunction Solar Cells. IEEE J. Photovolt. 2012, 2, 7-15. [CrossRef]

8. Ding, K.; Aeberhard, U.; Finger, F.; Rau, U. Silicon heterojunction solar cell with amorphous silicon oxide buffer and microcrystalline silicon oxide contact layers. Phys. Status Solidi Rapid Res. Lett. 2012, 6, 193-195. [CrossRef]

9. Battaglia, C.; DeNicolás, S.M.; DeWolf, S.; Yin, X.; Zheng, M.; Ballif, C.; Javey, A. Silicon heterojunction solar cell with passivated hole selective MoOx contact. Appl. Phys. Lett. 2014, 104, 113902. [CrossRef]

10. Peter Seif, J.; Descoeudres, A.; Filipič, M.; Smole, F.; Topič, M.; Charles Holman, Z.; DeWolf, S.; Ballif, C. Amorphous silicon oxide window layers for high-efficiency silicon heterojunction solar cells. J. Appl. Phys. 2014, 115, 024502. [CrossRef]

11. Sritharathikhun, J.; Jiang, F.; Miyajima, S.; Yamada, A.; Konagai, M. Optimization of p-type hydrogenated microcrystalline silicon oxide window layer for high-efficiency crystalline silicon heterojunction solar cells. Jpn. J. Appl. Phys. 2009, 48, 1016031-1016035. [CrossRef]

12. Lu, M.; Bowden, S.; Das, U.; Birkmire, R. Interdigitated back contact silicon heterojunction solar cell and the effect of front surface passivation. Appl. Phys. Lett. 2007, 91, 063507. [CrossRef]

13. Green, M.A.; Emery, K.; Hishikawa, Y.; Warta, W.; Dunlop, E.D. Solar cell efficiency tables (Version 45). Prog. Photovolt. 2015, 23, 1-9. [CrossRef]

14. Yang, J.; Banerjee, A.; Guha, S. Amorphous silicon based photovoltaics-From earth to the "final frontier". Sol. Energy Mater. Sol. Cells 2003, 78, 597-612. [CrossRef]

15. Andoh, N.; Nagayoshi, H.; Kanbashi, T.; Kamisako, K. Characterization of high-quality a-SiC: H films prepared by hydrogen-radical CVD method. Sol. Energy Mater. Sol. Cells 1997, 49, 89-94. [CrossRef]

16. Wang, Y.H.; Lin, J.; Huan, C.H. Multiphase structure of hydrogenated amorphous silicon carbide thin films. Mater. Sci. Eng. B 2002, 95, 43. [CrossRef]

17. Bullot, J.; Schmidt, M.P. Physics of Amorphous Silicon-Carbon Alloys. Phys. Status Solidi B 1987, 143, 345. [CrossRef]

18. Vasin, A.V.; Kolesnik, S.P.; Konchits, A.A.; Rusavsky, A.V.; Lysenko, V.S.; Nazarov, A.N.; Ishikawa, Y.; Koshka, Y. Structure, paramagnetic defects and light-emission of carbon-rich a-SiC:H films. J. Appl. Phys. 2008, 103, 123710. [CrossRef]

19. Robertson, J. Defects in Diamond-Like Carbon. J. Phys. Status Solidi A 2001, 186, 177. [CrossRef]

20. Yao, Y.; Xiao, S.; Zhang, X.; Gu, X. Simulation optimizing of $n$ type HIT solar cells with AFORS-HET Mod. Phys. Lett. B 2017, 31, 1740025.

21. Lisheng, W.; Fengxiang, C.; Yu, A. Simulation of high efficiency heterojunction solar cells with AFORS-HET. J. Phys. Conf. Ser. 2011, 276, 012177. [CrossRef]

22. Fortes, M.; Belfar, A.; Garcia-Loureiro, A.J. Two-dimensional simulation study of textured p-i-n a-Si:H solar cells with p-a-SiC:H and p-nc-Si:H window layers. Optik 2016, 127, 9464-9473. [CrossRef]

23. Cannella, G.; Principato, F.; Foti, M.; Di Marco, S.; Grasso, A.; Lombardo, S. Carrier transport mechanism in the SnO2: F/p-type a-Si:H heterojunction. J. Appl. Phys. 2011, 110, 024502. [CrossRef]

24. Liu, Y.; Sun, Y.; Liu, W.; Yao, J.H. Novel high-efficiency crystalline-silicon-based compound heterojunction solar cells: HCT (heterojunction with compound thin-layer). Phys. Chem. Chem. Phys. 2014, 16, 15400. [CrossRef]

25. Baek, S.; Lee, J.; Lee, Y.-J.; Iftiquar, S.M.; Kim, Y.; Park, J.; Yi, J. Interface modification effect between p-type a-SiC:H and ZnO: Al in p-i-n amorphous silicon solar cells. Nanoscale Res. Lett. 2012, 7, 81. [CrossRef]

26. Dao, V.A.; Lee, Y.; Kim, S.; Cho, J.; Ahn, S.; Kim, Y.; Lakshminarayan, N.; Yi, J. Effect of Valence Band Offset and Surface Passivation Quality in the Silicon Heterojunction Solar Cells. J. Electrochem. Soc. 2011, 158, H1129. [CrossRef]

27. Shen, L.; Meng, F.; Liu, Z. Roles of the Fermi level of doped a-Si: H and band offsets at a-Si: H/c-Si interfaces in n-type HIT solar cells. Sol. Energy 2013, 97, 168-175. [CrossRef]

28. Wang, F.; Du, R.; Ren, Q.; Wei, C.; Zhao, Y.; Zhang, X. Band alignment and enhancement of the interface properties for heterojunction solar cells by employing amorphous-nanocrystalline hierarchical emitter layers. J. Mater. Chem. C 2017, 5, 1751-1757. [CrossRef]

29. Pham, D.P.; Kim, S.; Park, J.; Cho, J.; Kim, H.; Le, A.H.T.; Yi, J. Role of a-Si:H buffer layer at the p/i interface and band gap profiling of the absorption layer on enhancing cell parameters in hydrogenated amorphous silicon germanium solar cells. Optik 2017, 136, 507-512. [CrossRef] 
30. Yu, F.; Huang, G.; Lin, W.; Xu, C. An analysis for S-shaped I-V characteristics of organic solar cells using lumped-parameter equivalent circuit model. Sol. Energy 2019, 177, 229-240. [CrossRef]

31. Huang, G.; Yu, F.; Xu, C. An Analytical Solution to Lumped Parameter Equivalent Circuit Model of Organic Solar Cells. Crystals 2018, 8, 224. [CrossRef]

32. Yu, F.; Huang, G.; Lin, W.; Xu, C. Lumped-Parameter Equivalent Circuit Model for S-Shaped Current-Voltage Characteristics of Organic Solar Cells. IEEE Trans. Electron Devices 2019, 66, 670-677. [CrossRef]

33. Zhang, C.F.; Zhang, J.C.; Hao, Y.; Lin, Z.H.; Zhu, C.X. A simple and efficient solar cell parameter extraction method from a single current-voltage curve. J. Appl. Phys. 2011, 110, 064504. [CrossRef]

(C) 2019 by the authors. Licensee MDPI, Basel, Switzerland. This article is an open access article distributed under the terms and conditions of the Creative Commons Attribution (CC BY) license (http://creativecommons.org/licenses/by/4.0/). 